ANNA BARAŃSKA

Instytut Historii Katolickiego Uniwersytetu

Lubelskiego Jana Pawła II

\title{
CHRZEŚCIJAŃSKOŚĆ - CZYM JEST I JAK JĄ MIERZYĆ? KILKA UWAG NATURY METODOLOGICZNEJ
}

Jak można zdefiniować „społeczeństwo chrześcijańskie” i co stanowi o jego chrześcijańskości? ${ }^{1}$ Nie jest przypadkiem, że pierwsze, zasadnicze pytanie ankiety związanej z 1050. rocznicą chrztu Mieszka I - nazywanej tradycyjnie rocznica , "chrztu Polski” - dotyczy po pierwsze definicji, a po drugie - narzędzi badawczych. Dla badań nad historią religii, religijnością czy historią społeczno-religijną, wymagających z natury rzeczy interdyscyplinarnej perspektywy, są to kwestie o fundamentalnym znaczeniu. Wystarczy jednak sięgnąć do literatury przedmiotu, aby przekonać się, że nawet tak podstawowe pojęcia jak chrystianizacja i dechrystianizacja (bądź węższe znaczeniowo: sekularyzacja czy laicyzacja), choć używane od dawna w naukach historycznych i społecznych, nie tylko mogą, ale powinny stać się przedmiotem pogłębionej refleksji.

W opublikowanym ponad 20 lat temu, ale nadal aktualnym artykule poświęconym badaniom nad historią społeczno-religijną Jerzy Kłoczowski napisał, że pierwszym pytaniem dla historyka zajmującego się tą dziedziną jest: „,za co się dany Kościół, dana wspólnota uważa, co podaje do wierzenia i jakie obowiązki nakłada na wiernych"2. W przypadku chrześcijaństwa odpowiedź na to pytanie stawia badaczy przed poważnym wyzwaniem. „U początku bycia chrześcijaninem nie ma decyzji etycznej czy jakiejś wielkiej idei, jest natomiast spotkanie z wydarzeniem, z Osobą, która nadaje życiu nową perspektywę, a tym samym decydujące ukierunkowa-

${ }^{1}$ Ze względu na obszerność problematyki i niewielkie rozmiary tekstu zdecydowałam się skorzystać z kwestionariusza zasugerowanego przez Redakcję i odnieść krótko do jego najważniejszych punktów.

${ }^{2}$ J. Kłoczowski, Historia społeczno-religijna, KH 100, 1993, 4, s. 279. 
nie" ${ }^{3}$ - tak, opierając się na wielowiekowej tradycji Kościoła, definiuje tożsamość wyznawcy Chrystusa Benedykt XVI (Joseph Ratzinger). Jeśli więc konstytutywny element chrześcijańskości stanowi relacja człowieka do „wydarzenia/Osoby” należącego do rzeczywistości transcendentnej, a tym samym niedostępnej poznaniu, to historyk winien się przyznać do pewnej bezradności. Innymi słowy - pogodzić się z tym, że każda definicja,jaką może zaproponować w ramach swojej dyscypliny, będzie rozmijała się $z$ autodefinicją sformułowaną na gruncie wiary chrześcijańskiej. Mimo to znajomość owej autodefinicji oraz całości chrześcijańskiego kerygmatu jest dla badacza niezbędna, ponieważ wiara religijna należy do czynników mających istotny wpływ na postępowanie zarówno jednostek, jak i wspólnot czy społeczności. Pewien rosyjski dyplomata w raporcie dotyczącym negocjacji z kardynałami Kurii Rzymskiej napisał, że ich nieprzejednany opór wobec żądań cesarza ,ugruntowany jest w przypadku wielu z nich na prawdziwej wierze religijnej, u wszystkich pozostałych zaś na obowiązku wyznawania tej wiary" ". Obracając tę konstatację na dyrektywę metodologiczną, można by powiedzieć, iż historyk powinien być świadomy, że religijna motywacja działania ludzkiego jest zjawiskiem realnym i niedającym się zredukować do czynników polityczno-ideologicznych, psychologicznych czy społecznych; że w środowiskach chrześcijańskich poszczególne jednostki mogą kierować się bądź głęboko zinterioryzowaną wiarą, bądź „obowiązkiem jej wyznawania” (różne postacie konformizmu religijnego); że wreszcie w procesie badawczym należy obie te postawy rozróżnić.

Co decyduje o chrześcijańskim charakterze społeczeństwa? Wybór kryterium formalnego, jakim może być np. przyjęcie chrztu przez większość członków badanej grupy, wydaje się rozwiązaniem najprostszym. Jednak tego rodzaju kryterium, przydatne w ujęciach statystycznych, zawodzi z reguły na gruncie historii społeczno-kulturowej. Historycy mierzą się z podobnym problemem, rozważając kwestie identyfikacji narodowej: rozróżnienie narodu etnicznego i narodu politycznego, narodowości i obywatelstwa, zagadnienia świadomości, samoidentyfikacji, asymilacji itp. Analogia nie jest oczywiście idealna, ale wyraźnie wskazuje na niewystarczalność wskaźników formalnych.

Czy o chrześcijańskości stanowi intelektualne przyswojenie prawd wiary - wszystkich bądź tylko fundamentalnych? Należy pamiętać, że chrześcijaństwo nigdy nie przybrało formy systemu religijnego dla elit, przeciw-

${ }^{3}$ Benedykt XVI, Deus Caritas est, encyklika z 25 XII 2005, wprowadzenie, 〈http:// www.vatican.va/holy_father/benedict_xvi/encyclicals/documents/hf_ben-xvi_enc_ 20051225_deus-caritas-est_pl.html〉.

${ }^{4}$ Vnešnââ politika Rossii XIX veka i načala XX veka, red. A.L. Naročnickij et al., t. 1(9), Moskva 1974, s. 245. 
nie - od początku miało charakter uniwersalny i kierowało swój przekaz do wszystkich ludzi, niezależnie od ich statusu społecznego i intelektualnego potencjału. Wymagania,jakie Kościół stawiał swoim wiernym w zakresie wiedzy religijnej, historyk może określić np. na podstawie treści katechezy przedchrzcielnej dorosłych katechumenów, praktykowanej od czasów starożytnych. Jak wiadomo, występowały tu znaczne różnice w zależności od okresu, terenu, stopnia przygotowania słuchaczy i lokalnych warunków (innych w krajach już schrystianizowanych, innych w krajach misyjnych). Na terenach schrystianizowanych, gdzie chrzczone były przede wszystkim niemowlęta, nauka prawd wiary przypadała zazwyczaj na okres dzieciństwa i odbywała się m.in. poprzez środowisko rodzinne, gminę, parafię lub szkołę. Wśród wiernych nierzadko występowało zjawisko „wtórnego analfabetyzmu" religijnego. W badaniach nad tym problemem należałoby odróżnić przynajmniej trzy sytuacje: niepełną znajomość prawd wiary połączoną z regularnymi praktykami czy nawet głębokim zaangażowaniem religijnym; ignorancję, której towarzyszy zaniedbanie praktyk; wreszcie ignorancję prowadzącą do synkretyzmu religijnego. $\mathrm{O}$ ile w pierwszym przypadku trudno byłoby kwestionować przynależność do społeczności chrześcijańskiej ludzi „prostej wiary”, nawet jeśli ich wiedza religijna ograniczała się do rudymentów, o tyle w pozostałych sprawa jest dyskusyjna. Warto również zauważyć, że znajomość prawd wiary, zasad moralnych czy nawet teologii chrześcijańskiej nie jest tożsama z ich akceptacją - posiadać ją może przecież, i to w wysokim stopniu, wyznawca innej religii lub ateista.

Czy z grona chrześcijan należy wyłączyć osoby, które nie przestrzegają głoszonych przez chrześcijaństwo zasad moralnych? Obie tradycje chrześcijańskie, zachodnia i wschodnia, zgadzają się, że wierny naruszający te zasady w sprawach najbardziej istotnych sam wyklucza się ze wspólnoty Kościoła - w pewnym stopniu (niemożliwość uczestnictwa w liturgii lub przyjmowania niektórych sakramentów) lub całkowicie (ekskomunika ipso facto). $Z$ drugiej strony obie dopuszczają absolucję najcięższych nawet przewinień w przypadku żalu i woli poprawy. Chrześcijańskie spojrzenie na kwestię zasad moralnych charakteryzowało się zawsze pewnym napięciem między stanowczym wezwaniem do ich przestrzegania i przekonaniem, że stan „,bezgrzeszności” nie może być osiągnięty na tym świecie, a życie moralne chrześcijanina obrazuje metafora nieprzerwanej walki. Nawet chrześcijanie par excellence, czyli święci chrześcijańskiego Zachodu i Wschodu, miewali w swoich życiorysach okresy, w których łamali podstawowe przykazania Dekalogu. Tym trudniej byłoby zastosować kryterium przestrzegania chrześcijańskich zasad moralnych do całych społeczności. Niemniej przyjąć trzeba, że w społeczeństwie chrześcijańskim Dekalog i prawo etyczne zawarte w nauce Chrystusa muszą stanowić wyraźny punkt odniesienia 
zarówno dla moralności indywidualnej, jak i zbiorowej - bądź przez to, że znalazły odzwierciedlenie w prawie stanowionym, bądź poprzez przeniknięcie do sfery mentalności, obyczajów i życia codziennego.

Kiedy więc można mówić o społeczeństwie chrześcijańskim? Wydaje się, że adekwatna definicja powinna uwzględniać kilka kryteriów. Po pierwsze, „większość kwalifikowaną” muszą stanowić w nim ludzie ochrzczeni, znający (stosownie do warunków epoki, środowiska itp.) i akceptujący podstawowe prawdy wiary chrześcijańskiej. Drugi warunek to chrystianizacja miejscowej kultury, czyli zintegrowanie jej z chrześcijańską wizją człowieka i świata oraz nauką moralną. Proces ten jest zawsze stopniowy i długotrwały. Fakt naruszania prawa moralnego przez członków społeczności nie przekreśla jej chrześcijańskiego charakteru, jeśli nie towarzyszy mu (w wymiarze społecznym) odrzucenie owego prawa jako takiego bądź zastąpienie go innym, opartym na odmiennym systemie wartości. Po trzecie, religijność ochrzczonych członków społeczności winna charakteryzować się wystarczającym stopniem zaangażowania i dynamizmu. Poziom „współczynnika religijności” (jak go tu nazywam roboczo) historyk może określić na podstawie jej uchwytnych przejawów, do których należą m.in.: udział w praktykach, podejmowanie przez jednostki i grupy chrześcijańskich form życia monastycznego czy pustelniczego, liczba kapłanów (powołań kapłańskich), działalność charytatywna i społeczna motywowana religijnie, rozwój religijnych ruchów i stowarzyszeń, obecność inspiracji chrześcijańskich w kulturze i sztuce itp. Analiza okresów wzrostu i spadku religijności na konkretnych obszarach (kraje, regiony) jest ważnym postulatem badawczym, choć trzeba zdawać sobie sprawę, że jest to zadanie znacznie trudniejsze od analizy koniunktur gospodarczych; nie może też ograniczyć się do elit czy nielicznych, wybranych środowisk. Warto zauważyć, że zawężenie pola obserwacji wyłącznie do uczestnictwa w niedzielnej liturgii czy przestrzegania tzw. praktyk paschalnych powoduje, iż otrzymane wyniki mają tylko względną wartość. Spełnianie nakazanych przez Kościół praktyk może być wynikiem religijnego konformizmu, natomiast o interioryzacji wiary świadczą działania wymagające głębokiego i długotrwałego zaangażowania osobistego. Właśnie dlatego zwrócenie uwagi na te ostatnie wydaje się konieczne przy ustalaniu „współczynnika religijności” (który w pewien sposób odzwierciedlałby również proporcje między liczebnością chrześcijan inspirowanych „prawdziwą wiarą religijną” i tych, których motywuje presja środowiska lub przymus zewnętrzny).

Zgodnie z powyższym chrześcijańskość należałoby uznać za pojęcie stopniowalne, zarówno w odniesieniu do jednostki, jak i w wymiarze społecznym. Konkretny człowiek staje się „lepszym” lub „gorszym” chrześcija- 
ninem w zależności od stopnia uwewnętrznienia swojej wiary i jej wpływu na postępowanie w sferze prywatnej i publicznej. Analogicznie społeczeństwo może być chrześcijańskie w mniejszym lub większym stopniu. Odnosi się to także do szerszego (i dyskusyjnego) pojęcia „cywilizacji chrześcijańskiej”. Spotkanie chrześcijaństwa z konkretną kulturą może doprowadzić do jej przekształcenia i nasycenia treściami chrześcijańskimi, co nie oznacza jednak całkowitej unifikacji tych dwóch elementów. Z jednej strony kultura ulega chrystianizacji, z drugiej - religia wpisuje się w określony kontekst kulturowy. Proces ten obrazują dobrze dzieje dwóch wielkich tradycji chrześcijańskich w Europie - łacińskiej, związanej z dziedzictwem cywilizacyjnym Cesarstwa Zachodniego, i wschodniej, określanej jako grecka bądź bizantyjska. Pytanie o wpływ chrystianizacji na zmiany w strukturach politycznych i społecznych oraz o to, czy była ona ,wehikułem modernizacji" ${ }^{5}$, sytuowałabym w tej właśnie perspektywie. W wielu wypadkach chrystianizacja oznaczała nie tylko zetknięcie się z nową religią, ale także z inną kulturą, już (w większym czy mniejszym stopniu) schrystianizowaną. Niełatwo jest więc rozstrzygnąć, które zmiany wiązały się z przyjęciem religii, a które byłyby wynikiem interakcji między kulturami. Takie rozróżnienie wydaje się zasadne zarówno w przypadku państw Wacława, Mieszka I czy Stefana, jak i terenów Nowego Świata.

Przyjmując, że nie jest uprawnione mówienie o jednej tylko cywilizacji chrześcijańskiej, należałoby także zastanowić się, dla jakich epok i obszarów możliwe jest użycie przymiotnika chrześcijański, dla jakich zaś właściwsze byłoby odnoszenie się do poszczególnych wyznań. Społeczności chrześcijańskie różnych denominacji bywały ze sobą silnie skonfliktowane - nie tylko w okresie reformacji czy wojen religijnych. W przypadku XIX stulecia, którym się zajmuję, bardziej zasadne wydaje się np. pytanie o katolickość polskiego społeczeństwa niż o jego chrześcijańskość - chyba że problem badawczy dotyczyłby wyłącznie procesów laicyzacji i dechrystianizacji.

Stwierdzenie, że chrześcijańskość społeczeństwa, kultury lub cywilizacji jest stopniowalna, a tym samym względna, należy uzupełnić drugim - że chrystianizacja jest procesem odwracalnym. Przyczyną dechrystianizacji mogą być czynniki zewnętrzne, takie jak militarny podbój przez najeźdźców ustosunkowanych wrogo do religii chrześcijańskiej (Bliski Wschód, Afryka) albo polityka władz państwowych w okresach

${ }^{5}$ Sformułowanie to nie wydaje się trafne. Teoria modernizacji jest genetycznie związana z badaniami nad kształtowaniem się nowoczesnego kapitalizmu i trudno przenosić ją np. na okres piastowski. Max Weber, twórca jej klasycznego ujęcia, uważał, że w procesie modernizacji każde $\mathrm{z}$ wielkich wyznań chrześcijańskich odegrało odmienną rolę. 
dyktatury lub totalitaryzmu (Francja za rządów jakobinów, ZSRR). Mogą również doprowadzić do niej procesy oddolne, czego przykład stanowi duża część współczesnej Europy. Dechrystianizacja uwidocznia się tam bardzo wyraźnie zarówno w wymiarze formalno-statystycznym (liczba ochrzczonych, częstotliwość praktyk), jak i na poziomie cywilizacyjnym (system prawny, obyczaje, kultura). Charakterystyczną cechą postchrześcijańskiego społeczeństwa wydaje się zachowanie pewnych wartości zaczerpniętych z chrześcijaństwa przy odrzuceniu (formalnym lub faktycznym) chrześcijaństwa jako religii. W wielu krajach europejskich osoby deklarujące swą przynależność do Kościoła katolickiego lub wspólnot protestanckich negują nie tylko chrześcijańską naukę moralną, ale także podstawowe prawdy wiary (Zmartwychwstanie, Sąd Ostateczny i in.) ${ }^{6}$.

Wyrażany w przeszłości pogląd, że dechrystianizacja łączy się zawsze z laicyzacją (tzn. przyjęciem postawy ateizmu lub agnostycyzmu motywowanego racjonalistycznie), budzi obecnie coraz więcej wątpliwości. Europejczycy odwracający się od chrześcijaństwa znacznie częściej niż w stronę racjonalizmu kierują się ku irracjonalnym (a nawet skrajnie irracjonalnym) postawom. Świadczy o tym popularność ruchów parareligijnych i różnego typu sekt, mistyki dalekowschodniej oraz ezoteryki (funkcjonującej na rynku jako coraz bardziej dochodowy biznes) ${ }^{7}$. Inne, stosunkowo nowe zjawisko to skuteczny prozelityzm islamski w krajach europejskich ${ }^{8}$.

Teza, iż (poczynając od wieku XIX) funkcję substytutu religii zaczęły pełnić ideologie, zasługuje z pewnością na uwagę. Wskazywałyby na to np. różne formy „ubóstwienia” rasy, narodu lub klasy społecznej oraz parareligijny ceremoniał w dwudziestowiecznych państwach totalitarnych. Inne, interesujące zjawisko to „religijnie” pojmowana laickość, aspirująca do roli nowego typu „wyznania panującego" i żądająca dla siebie wyłączności w sferze publicznej (m.in. poprzez wyrugowanie

${ }^{6}$ Przykładowe wyniki badań socjologicznych wśród polskich katolików zob.: CBOS, Religijność Polaków 2012, 〈http://www.humanizm.net.pl/religijnosc2012.html〉.

${ }^{7}$ W Polsce, gdzie proces dechrystianizacji jest mniej zaawansowany niż w Europie Zachodniej, w 2010 r. zarejestrowanych było blisko 15 tys. firm zajmujących się wróżeniem, a liczba wróżek i jasnowidzów (z uwzględnieniem szarej strefy) przekraczała 100 tys. osób. Koszt jednej wizyty - od kilkudziesięciu do nawet kilkuset złotych - dorównywał wysokości honorariów w prywatnym lecznictwie. (S. Czubkowska, Ezoteryczny telebiznes. Wróżki stawiaja na telewizje, „GazetaPrawna.pl” 31 XII 2010, 〈http://biznes.gazetaprawna.pl/ artykuly/475221,ezoteryczny_telebiznes_wrozki_stawiaja_na_telewizje.html $\rangle$ ).

${ }^{8}$ Według ankiety instytutu Faith Matters w Wielkiej Brytanii w 2001 r. było ponad 60 tys. islamskich konwertytów, w 2010 liczba to wzrosła do 100 tys. (w tym: 56\% białych Brytyjczyków i 16\% innych białych; średni wiek - 27,5 1.), <http://faith -matters.org/images/stories/fm-reports/a-minority-within-a-minority-a-report-on -converts-to-islam-in-the-uk.pdf $>$. 
z niej wszystkich symboli religijnych i sprowadzenie religii do jednej $\mathrm{z}$ form życia prywatnego).

Odróżnienie laicyzacji (światopoglądowej) od sekularyzacji (instytucjonalnej) wydaje się zasadne, nawet jeśli oba te zjawiska są blisko ze sobą związane. Laicyzacja zawsze prowadzi do dechrystianizacji, choć dechrystianizacja, jak już wspomniałam, nie musi łączyć się z laicyzacją. Bardziej skomplikowana wydaje się natomiast relacja między dechrystianizacją a sekularyzacją. Ilustrują to dobrze dzieje złożonych związków między władzą religijną i świecką, religią i państwem. Christianitas - „Rzeczpospolita chrześcijańska” w średniowiecznej Europie była fenomenem historycznym, funkcjonującym w określonych ramach kulturowo-cywilizacyjnych. Kres położyła jej reformacja, która podzieliła społeczeństwo chrześcijańskie łacińskiego Zachodu na skonfliktowane grupy wyznaniowe. Przyjęcie zasady cuius regio eius religio zakłóciło względną równowagę między władzą kościelną i świecką na korzyść tej drugiej; ponadto "religią panującą" nie było już odtąd chrześcijaństwo, ale albo katolicyzm, albo któraś z denominacji protestanckich. Pogłębił się też podział między zachodnim a wschodnim chrześcijaństwem, gdzie stosunki między państwem, Kościołem i społecznością wierzących miały własną specyfikę i odrębną drogę ewolucji. Nowa formuła stosunków państwowo-kościelnych pojawiła się na gruncie przygotowanym przez wstrząsy rewolucji francuskiej. Jej twórcą był Napoleon Bonaparte, który do konkordatu z 1801 r. wprowadził pojęcie „religii znacznej większości obywateli”. Państwo gwarantowało wyznaniu „większościowemu” opiekę i uprzywilejowanie prawne (w mniejszym jednak stopniu niż w przypadku „religii panującej”), abstrahując od kwestii jego „prawdziwości" i odwołując się otwarcie do pragmatyki i statystyki. W ten sposób zrodzona w IV w. formuła państwa chrześcijańskiego, zachwiana w okresie reformacji, w wieku XIX znalazła się w fazie schyłkowej. Wraz z postępującą sekularyzacją aparatu państwowego i przejmowaniem zadań związanych z opieką nad Kościołem przez świecką biurokrację (wcześniej należały one do monarchy) związek tronu i ołtarza stawał się coraz bardziej problematyczny. Proces oddzielenia Kościoła od państwa dokonywał się stopniowo i nacechowany był wieloma konfliktami; przybrał też ostatecznie różne formy, określane czasem jako separacja czysta (Stany Zjednoczone), separacja wroga (Francja) i separacja skoordynowana (Niemcy).

${ }^{9}$ Termin „religia państwowa”, chociaż upowszechniony w literaturze, uważam za nieprecyzyjny i mylący, zwłaszcza jeśli stosuje się go dla zupełnie odmiennych epok i systemów politycznych. 
Idea rozdziału Kościoła od państwa spotykała się dość długo z gwałtownym sprzeciwem hierarchii kościelnej i wielu środowisk zaangażowanych religijnie katolików bądź protestantów, którzy uważali ją za przejaw dechrystianizacji. Podobne reakcje (w przypadku Kościoła katolickiego) wywołała likwidacja Państwa Kościelnego i pozbawienie papieża statusu świeckiego monarchy. Z czasem jednak w tych samych kręgach coraz więcej zwolenników zaczęła zyskiwać inna interpretacja, wedle której zaistniałe zmiany przyniosły Kościołowi katolickiemu i innym wyznaniom chrześcijańskim więcej korzyści niż szkody, uwalniając religię z wielowiekowej zależności od władzy świeckiej i wzmacniając autorytet moralny biskupa Rzymu. Podobną opinię wyrażali zresztą już w XIX w. niektórzy z życzliwych Kościołowi liberalnych demokratów ${ }^{10}$. Ambiwalentne skutki, jakie miała dla „religii panującej” opieka władz państwowych, można zauważyć zarówno w dziejach chrześcijaństwa zachodniego, jak i w kręgu prawosławia. Dlatego też pogląd, że każda forma sekularyzacji miałaby prowadzić do dechrystianizacji, trudno uznać za uzasadniony.

I wreszcie ostatnie pytanie: co decyduje o trwaniu względnie uwiądzie religii? Nie kwestionując znaczenia czynników politycznych i gospodarczych, mechanizmów społecznych, zmian kulturowych i innych uwarunkowań zewnętrznych, uważam, że w ostatecznym rozrachunku decyduje o tym najpotężniejsza i najbardziej nieuchwytna siła działająca w historii - wybory podejmowane przez poszczególnych ludzi.

${ }^{10}$ Alexis de Tocqueville napisał w 1835 r., że „sprzymierzając się z władzą polityczną, religia umacnia swe władanie nad niektórymi ludźmi, tracąc nadzieję panowania nad wszystkimi”. Cyt. za: Historia Kościoła, t. 4, red. L.J. Rogier, R. Bertier de Sauvigny, J. Hajjar, Warszawa 1987 (oryg. franc. 1966), s. 277. 